\title{
Geochemistry of siliciclastic rocks from the Shemshak Group (Upper Triassic-Middle Jurassic), northeastern Alborz, northern Iran: implications for palaeoweathering, provenance, and tectonic setting
}

\author{
Azizollah TAHERI ${ }^{1}$, Mahdi JAFARZADEH ${ }^{1, *}$, John S. ARMSTRONG-ALTRIN ${ }^{2}$ \\ and Seyed Reza MIRBAGHERI ${ }^{1}$ \\ 1 Shahrood University of Technology, Department of Earth Sciences, Shahrood, Iran \\ 2 Universidad Nacional Autónoma de México, Unidad de Procesos Oceánicos y Costeros, Instituto de Ciencias del Mar y \\ Limnología, Ciudad Universitaria, Ciudad de México 04510, México
}

Taheri, A., Jafarzadeh, M., Armstrong-Altrin, J.S., Mirbagheri, S.R., 2018. Geochemistry of siliciclastic rocks from the Shemshak Group (Upper Triassic-Middle Jurassic), northeastern Alborz, northern Iran: implications for palaeoweathering, provenance, and tectonic setting. Geological Quarterly, 62 (3): 522-535, doi: 10.7306/gq.1433

\begin{abstract}
Combined petrographic and geochemical data of the siliciclastic sedimentary rocks from the Shemshak Group in the northeastern Alborz Mountains, north of Iran are described, together with their implications for palaeoweathering, their provenance, and tectonic setting. Based on field observations and modal composition, the sandstones are classified as litharenites. The chemical index of alteration $(\mathrm{CIA})$ indicated that the source terrains underwent a moderate intensity of chemical weathering. The index of chemical variation (ICV) values indicated that the Shemshak Group rocks were immature and related to a source area with an active tectonic regime. Major, trace and rare earth element (REE) data suggested the domination of mixed sedimentary (recycled) and igneous rocks in the source area of the Shemshak Group. Petrographic and geochemical characteristics of Shemshak Group rocks suggest an active continental margin (ACM), which corresponds to the collision of the Iran plate with the Turan plate.
\end{abstract}

Key words: Shemshak Group, geochemistry, provenance, palaeoweathering, tectonic setting.

\section{INTRODUCTION}

The geochemistry of siliciclastic rocks is strongly influenced by various factors including source rock composition, tectonic setting, weathering, transportation mechanism as well as depositional and diagenetic processes (Suttner, 1974; Roser and Korsch, 1986). Many studies have documented that the geochemical composition of sandstones and shales provides significant clues to assess provenance, tectonic setting and palaeoclimate of the source area (e.g., McLennan et al., 1993; Cullers, 2000; Armstrong-Altrin, 2009; Nagarajan et al., 2015, 2017; Armstrong-Altrin et al., 2017, 2018). The siliciclastic Shemshak Group (Upper Triassic-Middle Jurassic) is one of the most extensive lithostratigraphic units of the Iran Plate, widespread across the northern Alborz and East Central Iran of the Iranian plate (Tabas and North of Kerman; Fürsich et al., 2009). Numerous studies have documented

\footnotetext{
* Corresponding author, e-mail: m_jafarzadeh@shahroodut.ac.ir Received: February 28, 2018; accepted: May 23, 2018; first published online: October 24, 2018
}

lithostratigraphic, sedimentological and palaeontological aspects of the Shemshak Group (e.g., Seyed-Emami et al., 2006; Fürsich et al., 2009; Shekarifard et al., 2009; Zanchi et al., 2009; Moosavirad et al., 2011, 2012; Abbassi and Madanipour, 2014; Salehi et al., 2017). These studies have shown that the Shemshak Group is composed largely of siliciclastic rock, locally reaching up to $4000 \mathrm{~m}$ in thickness. There are widespread coal beds in this siliciclastic succession and its sedimentary environments range from proximal alluvial fans to deep marine (Fürsich et al., 2005, 2009; Zanchi et al., 2009). From a palaeotectonic point of view, there are two unconformities at the top and bottom of Shemshak Group: bauxite-laterite deposits characterize the contact with the underlying platform carbonates of the Elikah Formation; the contact with the overlying platform represents a sharp change from siliciclastic rocks to Middle-Upper Jurassic carbonate platform-basin rocks (Fürsich et al., 2009, 2017). Nevertheless, the provenance and source area conditions of the Shemshak Group siliciclastic rocks in the Alborz Mountain, in terms of petrography and geochemistry of the sandstones and shales, have not previously been studied in detail. This study examines the petrography and geochemistry of siliciclastic rocks of the Shemshak Group in the northeastern Alborz Mountain and investigates the source rock characteristics, palaeoweathering and tectonic setting of the source terrain. 


\section{GEOLOGICAL SETTING AND STRATIGRAPHY OF THE STUDY AREA}

Alborz Mountain in northern Iran is a part of northern Himalayan-Alpine range, located around the southern parts of the Caspian Basin (Rad, 1986). The collision between the Iran and Turan plates (part of Eurasia) in the Late Triassic was mainly responsible for the present framework of Alborz with an overall $>12 \mathrm{~km}$ thick exposed Precambrian to Recent sedimentary succession (Stocklin, 1968; Rad, 1986; Zanchi et al., 2009). The uppermost Precambrian-Middle Triassic part of these sedimentary successions was deposited along a passive continental margin setting. During the Middle-Late Triassic, Eo-Cimmerian orogenesis deformed the successions and the terrigeneous Shemshak Group (Upper Triassic-Middle Jurassic) overlies this succession with angular unconformity. The siliciclastic Shemshak Group is widespread across large areas of the Iran plate especially in northern Alborz and East Central Iran (Fürsich et al., 2009; Wilmsen et al., 2009; Fig. 1). During the end of the Middle Triassic, the Iran plate, which was originally part of the northern Gondwana, collided with the Turan plate of Eurasia (e.g., Saidi et al., 1997; Stampfli and Borel, 2002). After this Early Cimmerian orogeny, the Palaeotethys Ocean between the Gondwana and Eurasia was closed. This event resulted in the deposition of shallow-water carbonates (Middle
Triassic) of the Elika Formation in Alborz being replaced by siliciclastic sedimention of the Shemshak Group.

Assereto (1966) defined the Shemshak Formation, the type area being near the Shemshak area, north of Tehran situated in the upper Ruteh Valley. Because of its immense thickness in different areas of Alborz and Central Iran, its rank was changed to a Group (e.g., Corsin and Stampfli, 1977; Seyed-Emami, 2003; Fürsich et al., 2009). Corsin and Stampfli (1977) divided the Shemshak Group of northeastern Alborz into three members: lower (Upper Triassic), middle (Lower Jurassic) and upper members (Middle Jurassic) (Fig. 2). The Shemshak Group deposits are commonly referred to as terrestrial deposits (fluvial and deltaic; Rad, 1986), however, based on the fossil assemblages a few authors assigned marine intervals that are reported from several localities (e.g., Fürsich et al., 2009). The Shemshak Group, in the eastern and northeastern Alborz Basin, disconformably rests on the Elika Formation. A ferricrete palaeosol zone associated with this disconformity indicates subaerial exposure of the Triassic rocks (Rad, 1986). The Shemshak Group is conformably overlain by the Farsian Formation, the contact being marked by a distinct lithological change (Najafi-Hajipour, 2009; Fig. 2). The Farsian section in the Ghoznavi-Farsian area, which is located along the Shahrood-Azadshahr road, has been measured in this study (Fig. 1). In the study area, the thickness of the Shemshak Group is $\sim 1250 \mathrm{~m}$ (Fig. 3) and the base of the section studied (lower

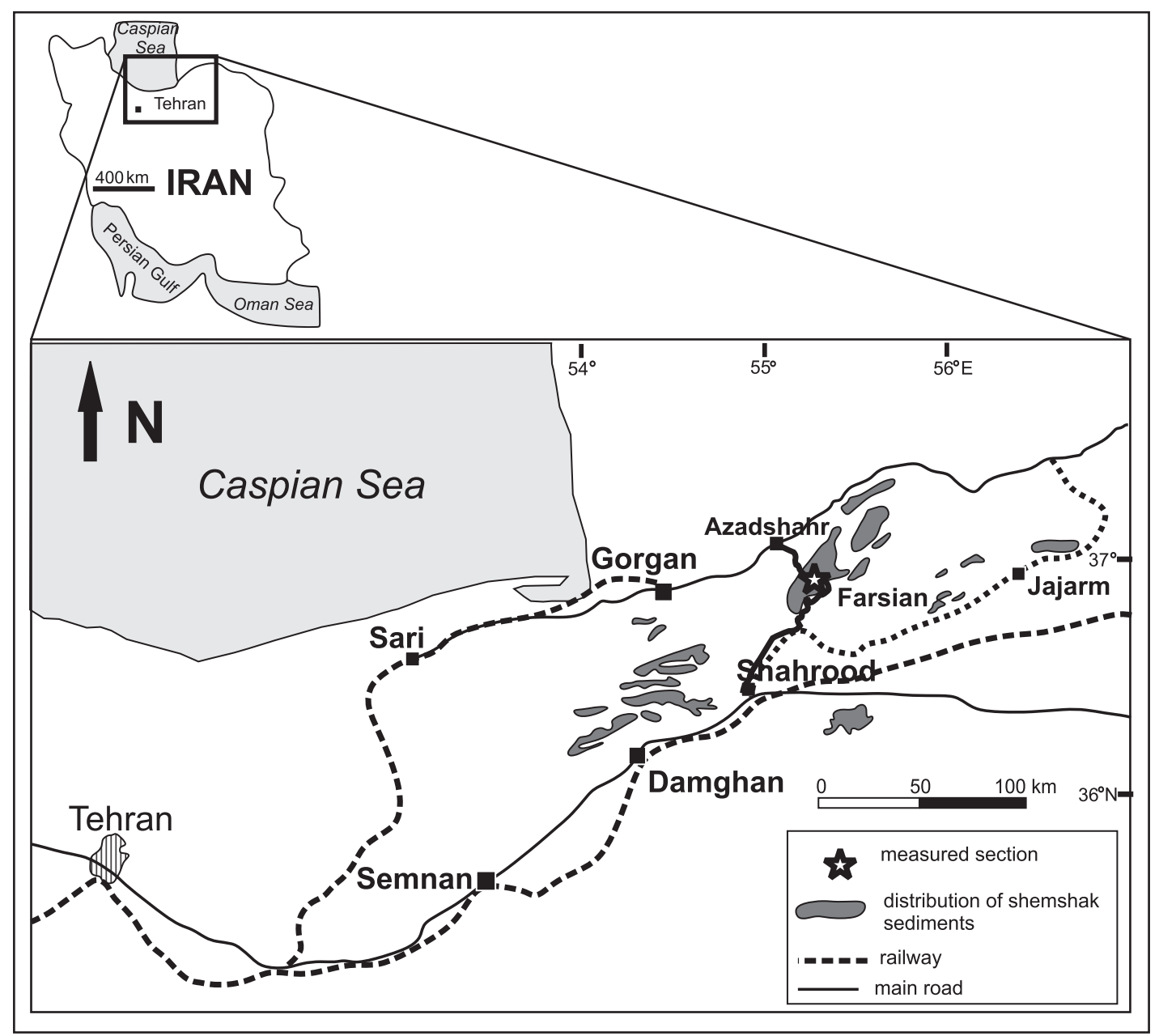

Fig. 1. Location map showing the distribution of the Shemshak Group deposits in the eastern Alborz Range of northern Iran 


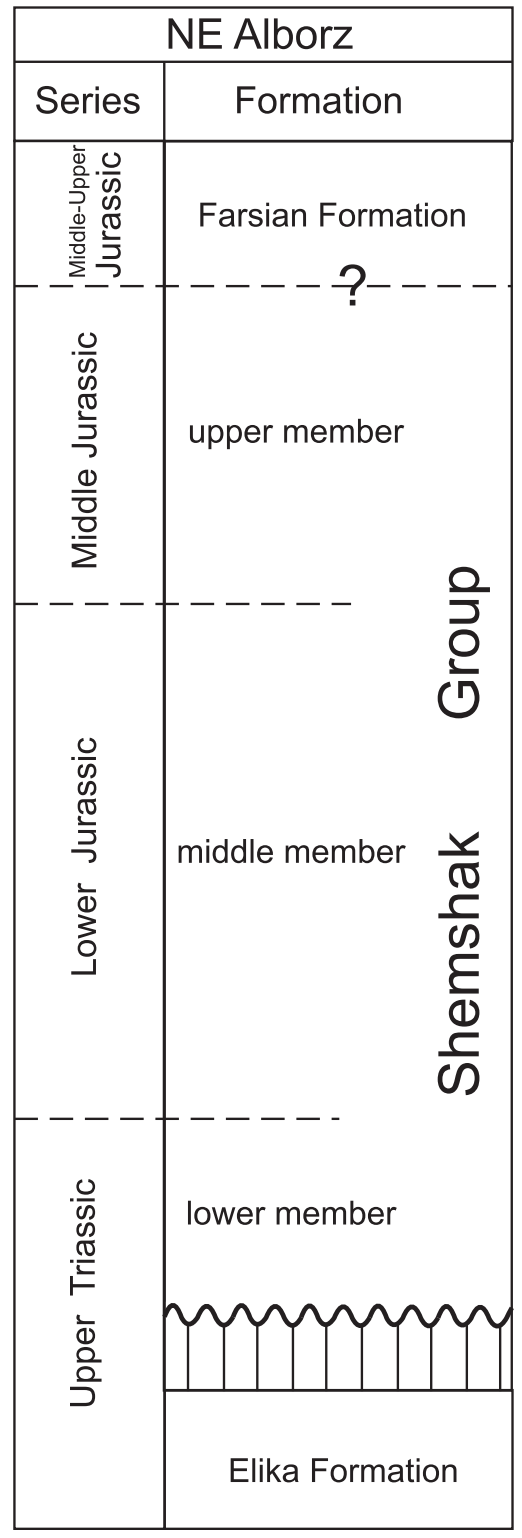

Fig. 2. Lithostratigraphic column of the Shemshak Group in northeastern Alborz (Corsin and Stampfli, 1977); not to scale

member) is represented by sandstones with intercalation of shales and siltstones (Fig. 4A). This part is overlain by sandstones and shales of the middle member, arranged in thickening upwards cycles (Fig. 4B). The sandstones are fine to medium-grained, some parts showing erosional bases locally with clay chips. Sedimentary structures include planar cross-stratification and asymmetrical ripple marks (Fig. 4C). Plant remains and root horizons are prevalent throughout the succession. The strata are often olive-grey in colour. The upper member of the Shemshak Group is characterized by monotonous, dark grey-olive-grey shale (Fig. 4D). The coal deposits of the Shemshak Group were derived from this upper member.

\section{METHODS}

Fifty sandstone and shale samples were collected from the Farsian section. Among them, 16 fresh sandstone samples were selected for detailed petrographic analysis and the Gazzi-Dickinson method was used for the point-counting analysis (Ingersoll et al., 1984). The strategy for sample selection was based on petrography to choose the least altered, fine- to medium grained sand-size samples, and to represent the entire succession of the Shemshak Formation. Nineteen sandstone and 6 shale samples were selected to determine their chemical composition. Geochemical analysis of crushed and powdered samples was done at Acme Analytical Laboratories, Canada. Analysis package $L F 200$ was chosen due to its extensive list of elements analysed. Major oxides and minor elements were analysed following a lithium metaborate/tetraborate fusion ICP-ES and REE were analysed by ICP mass spectrometry. Weight difference after ignition at $1000^{\circ} \mathrm{C}$ was used to determine loss on ignition (LOI). Each analysis was done in duplicate with a reproducibility found to be $<2 \%$. Analyses of standard materials indicate that the results are generally accurate to within $\pm 10 \%$.

\section{RESULTS}

\section{PETROGRAPHY}

The petrography of the sandstones of the Shemshak Group at the Farsian section was analysed to define the provenance and tectonic setting. Detrital modal composition of the sandstones, recalculated to percentage, is reported in Appendix $1^{*}$. The major constituents characterized in these sandstones are quartz (monocrystalline and polycrystalline), feldspars and rock fragments. Among quartz grains, monocrystalline quartz $(\mathrm{Qm})$ is higher than polycrystalline quartz. Monocrystalline quartz grains show straight to slightly undulose extinction (Fig. 5A, B). The sandstones contain minor amounts of feldspar grains including K-feldspar and plagioclase, with plagioclase dominating over K-feldspars (Fig. 5B). The rock fragments are dominantly sedimentary (chert, shale and siltstone fragments, respectively) and metamorphic fragments (phyllite and schist fragments, respectively; Fig. 5C, D).

\section{GEOCHEMISTRY}

Major element concentrations. The major element concentrations of the Shemshak Group sandstones are reported in Appendix 2. The sandstones of the Farsian section have moderate $\mathrm{SiO}_{2}$ contents ranging from 45.4 to 82.5 wt. \% (mean $67 \%$; Appendix 2). The $\mathrm{SiO}_{2}$ contents of shales from the Farsian section vary from 58.1 to 71.5 wt. $\%$ (mean $62.3 \%$ ). $\mathrm{Al}_{2} \mathrm{O}_{3}$ content ranges from 4.9 to $10.9 \%$ (mean $7.3 \%$ ) in the sandstones. In contrast, shale samples have higher $\mathrm{Al}_{2} \mathrm{O}_{3}$ contents ranging from 13.7 to $19.2 \%$ (mean $17.53 \%$ ). Both sandstone and shale have similar $\mathrm{K}_{2} \mathrm{O}$ contents (mean $0.96 \%$ and respectively). Chemical composition of detrital sediments depends on grain- 


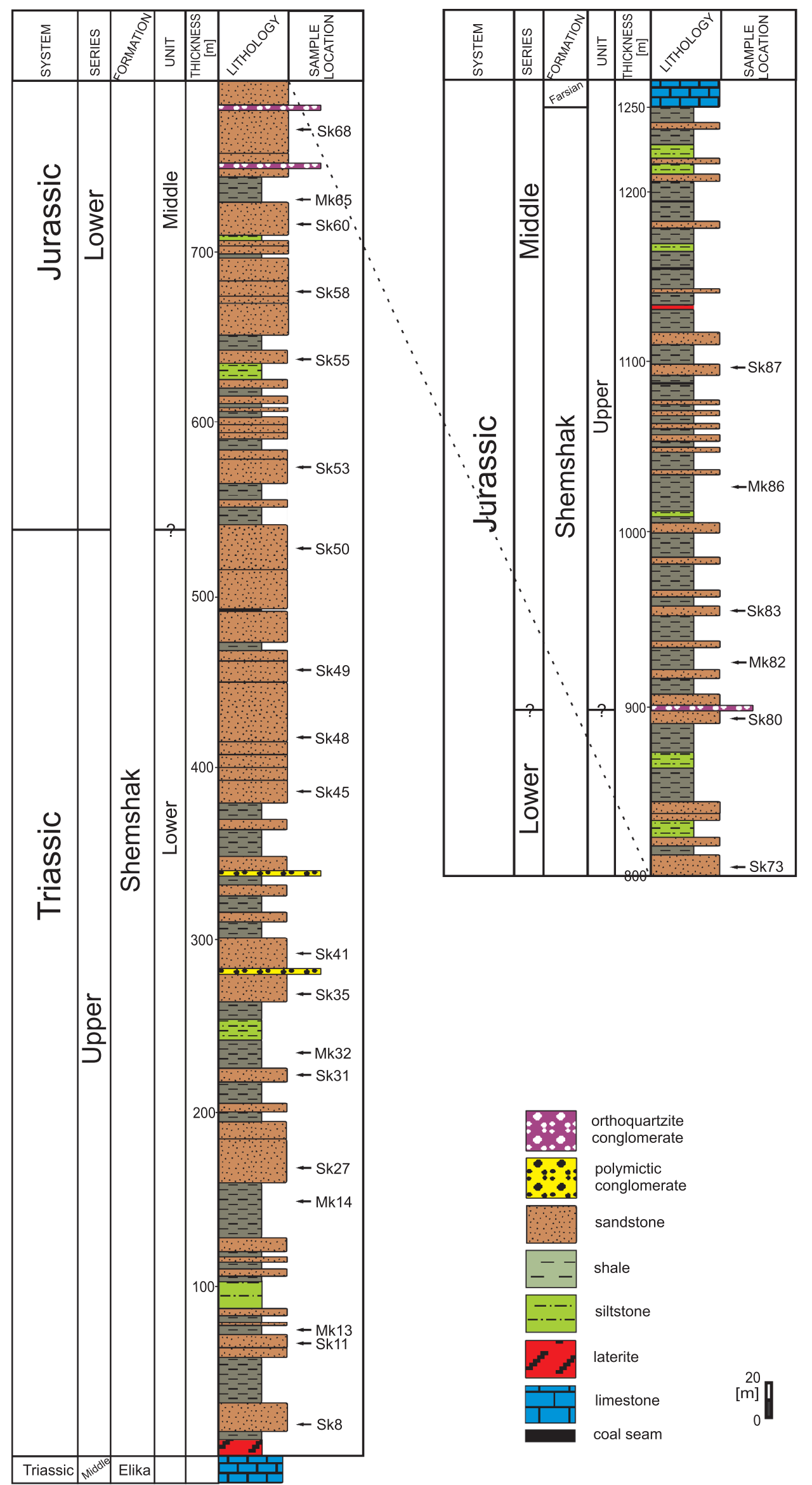

Fig. 3. Lithostratigraphic column of the Shemshak Group in the Farsian outcrop 

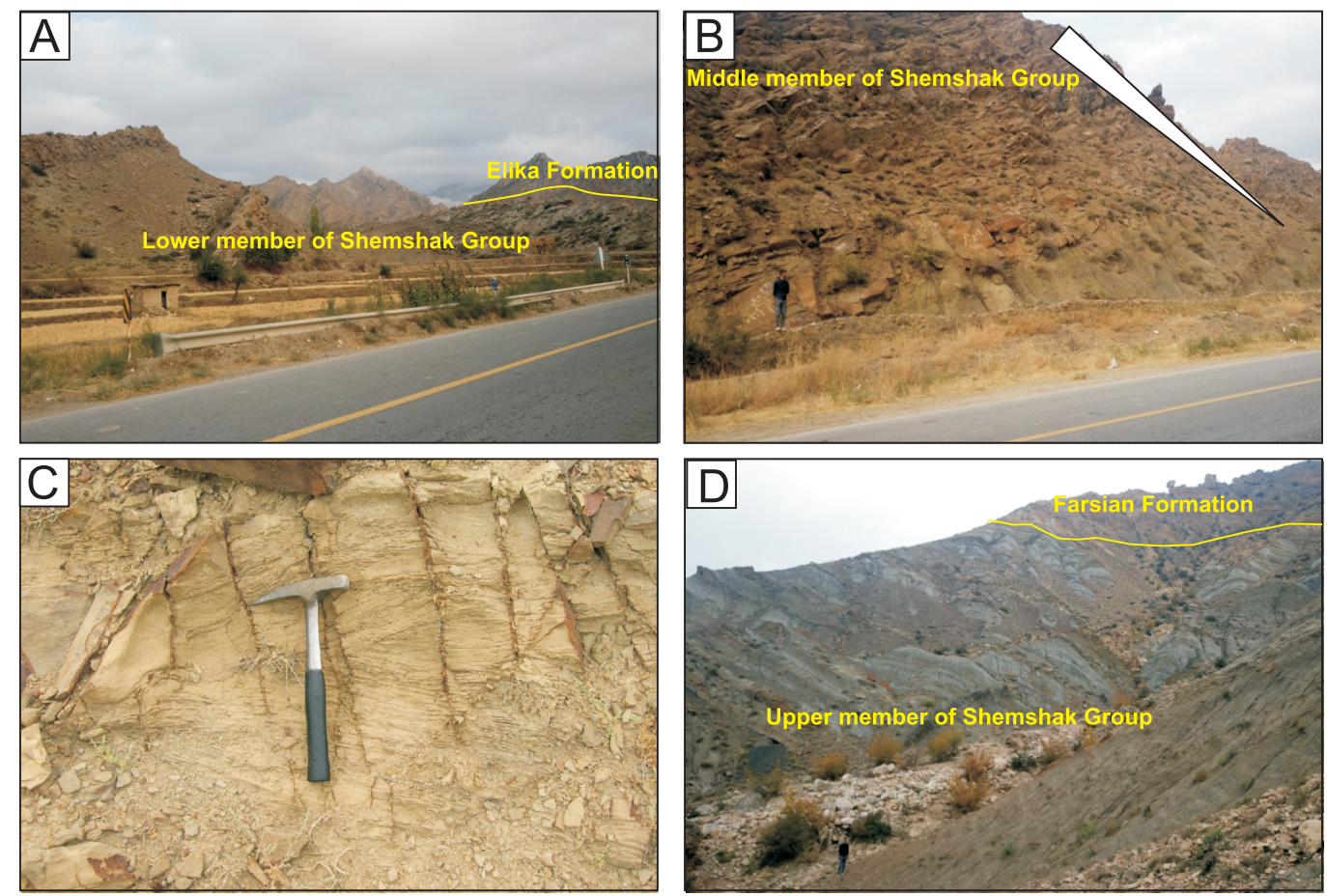

Fig. 4. Field photographs of Shemshak Group strata

A - lower boundary of the Shemshak Group with the Elika Formation near the village of Ghoznavi; B - thickening and coarsening-upwards cycles in sandstones and shales of the middle member; C - planar cross-bedding in sandstones of the middle member of Shemshak Group; D - upper boundary of the Shemshak Group with the Farsian Formation in south of the village of Farsian
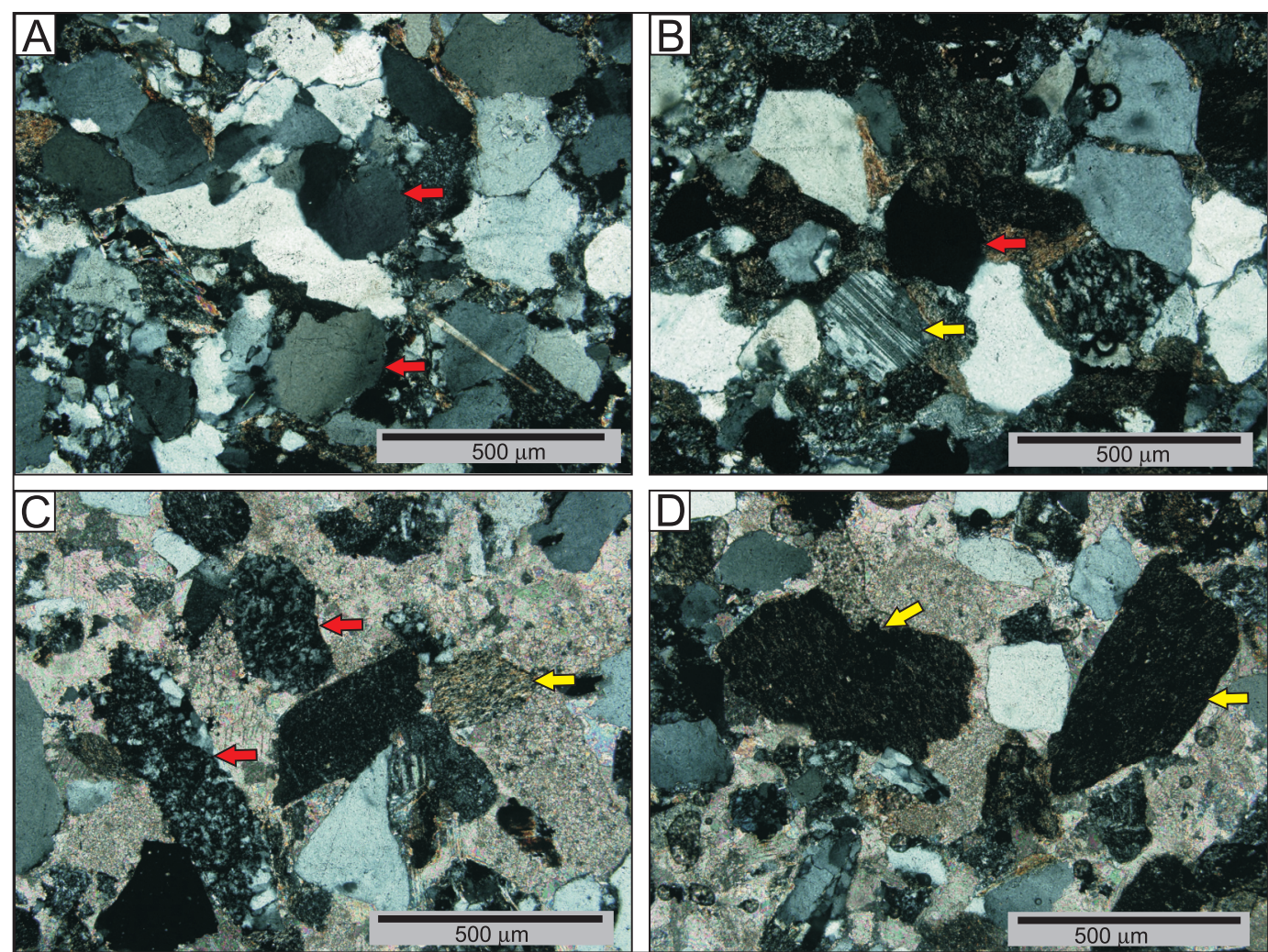

Fig. 5. Selected thin-section photomicrographs of detrital grains of sandstones from the Shemshak Group

A - photomicrograph showing mainly monocrystalline quartz grains with slightly undulose extinction (red arrows). B - quartz grain with straight extinction (red arrow) and plagioclase (yellow arrow) grain with twinning; C - sedimentary chert (red arrows) and metamorphic rock fragments (yellow arrow); D - shale fragments (yellow arrows) in sandstone with a carbonate cement 

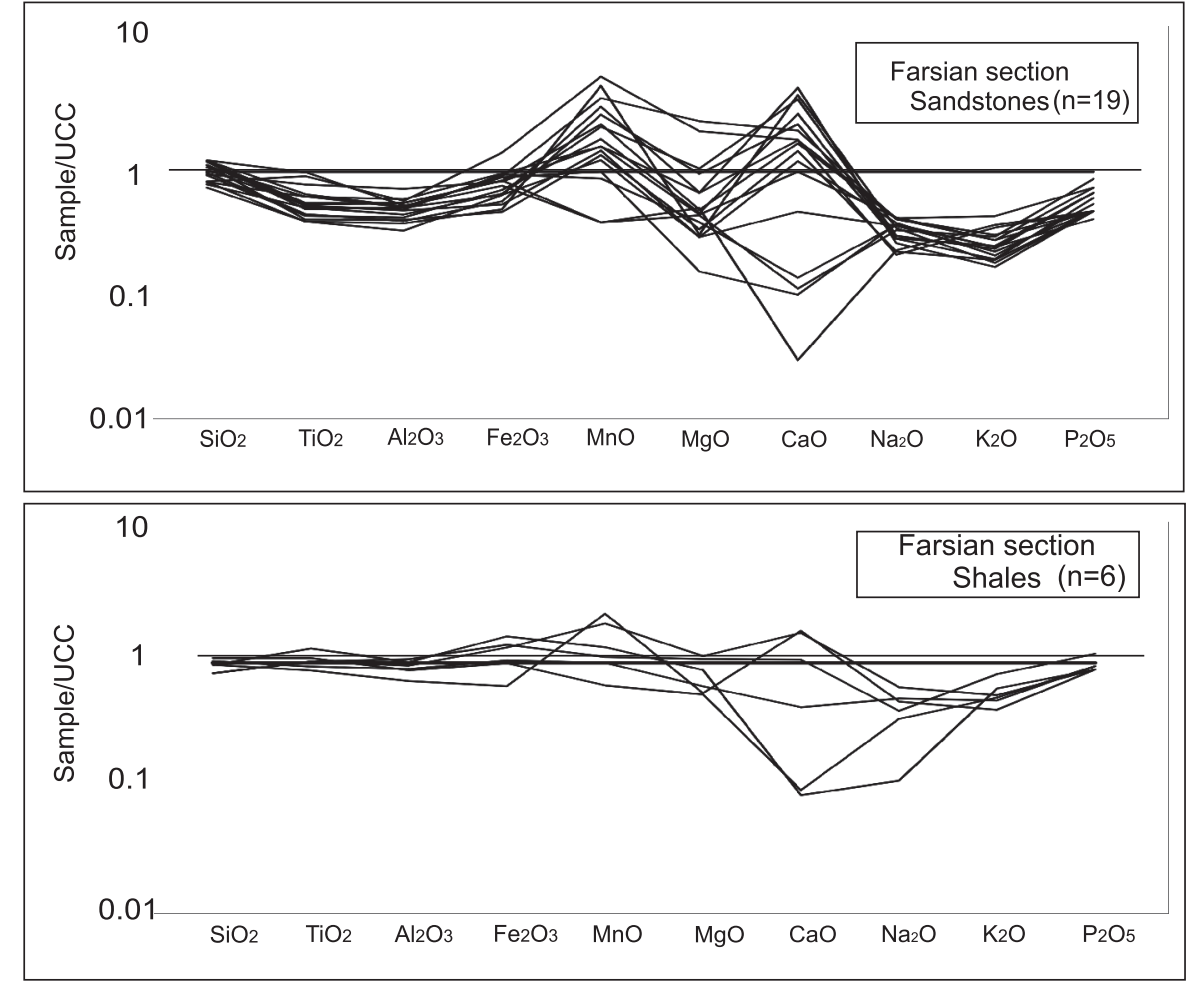

Fig. 6. Upper continental crust normalized major-element diagram for the Shemshak Group sandstone and shale samples (Taylor and McLennan, 1985)

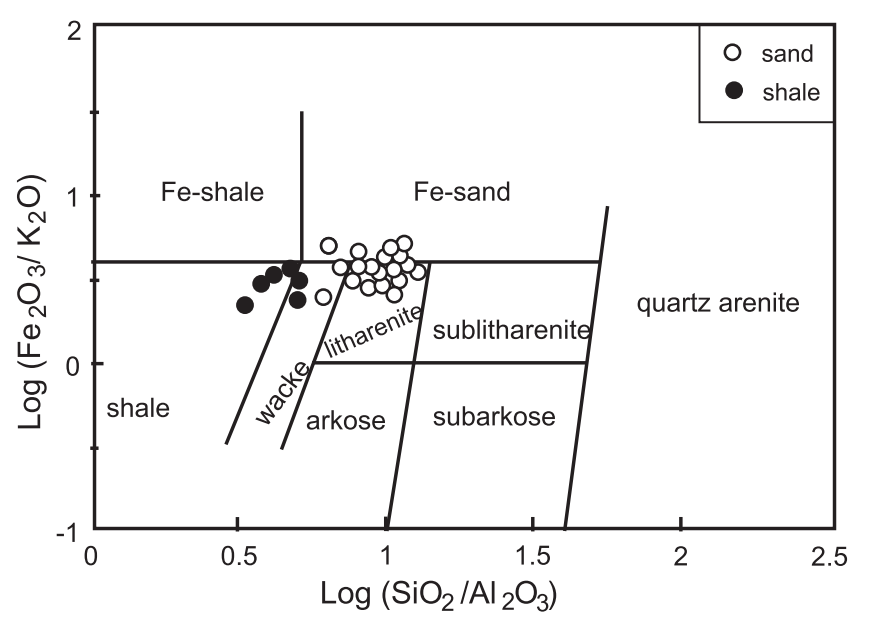

Fig. 7. Geochemical classification of sandstone and shales of the Shemshak Group (Herron, 1988)

-size, with high $\mathrm{Al}_{2} \mathrm{O}_{3}$ content in fine-grained sands and high $\mathrm{SiO}_{2}$ in coarse-grained sands, which also is reflected in the mineralogical composition (Vital and Stattegger, 2000; Armstrong-Altrin et al., 2013, 2015). $\mathrm{Fe}_{2} \mathrm{O}_{3}$ content in the sandstones ranges from 2.3 to $7.2 \%$ (mean $3.76 \%$ ) in the Farsian section. By contrast, shale samples have slightly higher $\mathrm{Fe}_{2} \mathrm{O}_{3}$ contents and vary from 3.1 to $8.7 \%$ (mean $6.0 \%$ ). By comparison with average upper continental crust (UCC; Taylor and McLennan, 1985) the $\mathrm{MnO}$ and $\mathrm{CaO}$ contents in the Farsian sandstones are slightly enriched, but $\mathrm{TiO}_{2}, \mathrm{P}_{2} \mathrm{O}_{5}, \mathrm{MnO}, \mathrm{Al}_{2} \mathrm{O}_{3}, \mathrm{Fe}_{2} \mathrm{O}_{3}$ as well as $\mathrm{Na}_{2} \mathrm{O}, \mathrm{K}_{2} \mathrm{O}$ are depleted (Fig. 6). The shale samples show slightly depleted $\mathrm{Na}_{2} \mathrm{O}$ and $\mathrm{K}_{2} \mathrm{O}$ contents, whereas $\mathrm{MnO}$ is slightly enriched by comparison with UCC. Based on the Herron (1988) diagram, the samples analysed are classified as shales, wackes and litharenites (Fig. 7), consistent with the petro- graphic data (Fig. 5). In Figure 8, a linear trend from sand to mud is observed, which is due to the grain-size variations in the detrital sediments. However, $\mathrm{Na}_{2} \mathrm{O}, \mathrm{MnO}$ and $\mathrm{CaO}$ show different patterns. In the sandstones, $\mathrm{Na}_{2} \mathrm{O}$ is positively correlated with $\mathrm{Al}_{2} \mathrm{O}_{3}$, while this correlation is negative for the shale samples. In the sandstones and shales, $\mathrm{MnO}$ and $\mathrm{CaO}$ are negatively correlated against $\mathrm{Al}_{2} \mathrm{O}_{3}$. The correlation is not significant between $\mathrm{SiO}_{2}$ and $\mathrm{Al}_{2} \mathrm{O}_{3}$ in the sandstone and shale indicating that much of the $\mathrm{SiO}_{2}$ is present as quartz grains (Armstrong-Altrin et al., 2013, 2014). This observation is consistent with the high concentration of $\mathrm{SiO}_{2}$ in the sandstones and shales (>63\%; mean value 82 and $67 \%$, respectively; Appendix 2).

Trace and rare earth element concentrations. The trace and REE concentrations of the Shemshak Group are listed in Appendix 3 and 4, respectively. The UCC-normalized trace element concentrations are shown in Figure 9. In comparison with average $\mathrm{UCC}, \mathrm{Sr}, \mathrm{Rb}$ and $\mathrm{Ba}$ in the Farsian section is strongly depleted. Other trace elements such as $\mathrm{Nb}, \mathrm{U}, \mathrm{Th}, \mathrm{Hf}$ and $\mathrm{Zr}$ are slightly depleted relative to UCC. However, samples SF80, SF45 and SF83 are enriched in Hf and Zr. The trace elements with values higher than $100 \mathrm{ppm}$ are $\mathrm{Zr}$ (78-259 ppm in the sandstones and 174-306 ppm in the shales) and $\mathrm{Sr}$ (58-222 ppm in the sandstones and 56-123 ppm in the shales), while the concentration of other trace elements is $<100 \mathrm{ppm}$. The content of total REE (?REE) varies from 73 to $147 \mathrm{ppm}$ in the sandstones (average $=93$ $\mathrm{ppm}$ ) and from 134 to 171 in the shales (average $=148.14$ $\mathrm{ppm})$. The concentration of light REE in the sandstones and shales ( 8-15.5 and $\sim 15.7-22$ ppm, respectively) is higher than that of the heavy REEs ( 8-15.5 and $\sim 16-22$ ppm, respectively). The chondrite-normalized REE patterns of the Shemshak Group sandstones and shales are shown in Figure 10. The ?REE content varies widely and all samples show LREE-enriched flat HREE patterns. The Eu anomaly is negative and the mean value of $\mathrm{Eu} / \mathrm{Eu}^{*}$ is 0.71 in sandstones and 0.67 in shales of the Farsian section (Fig. 10). 


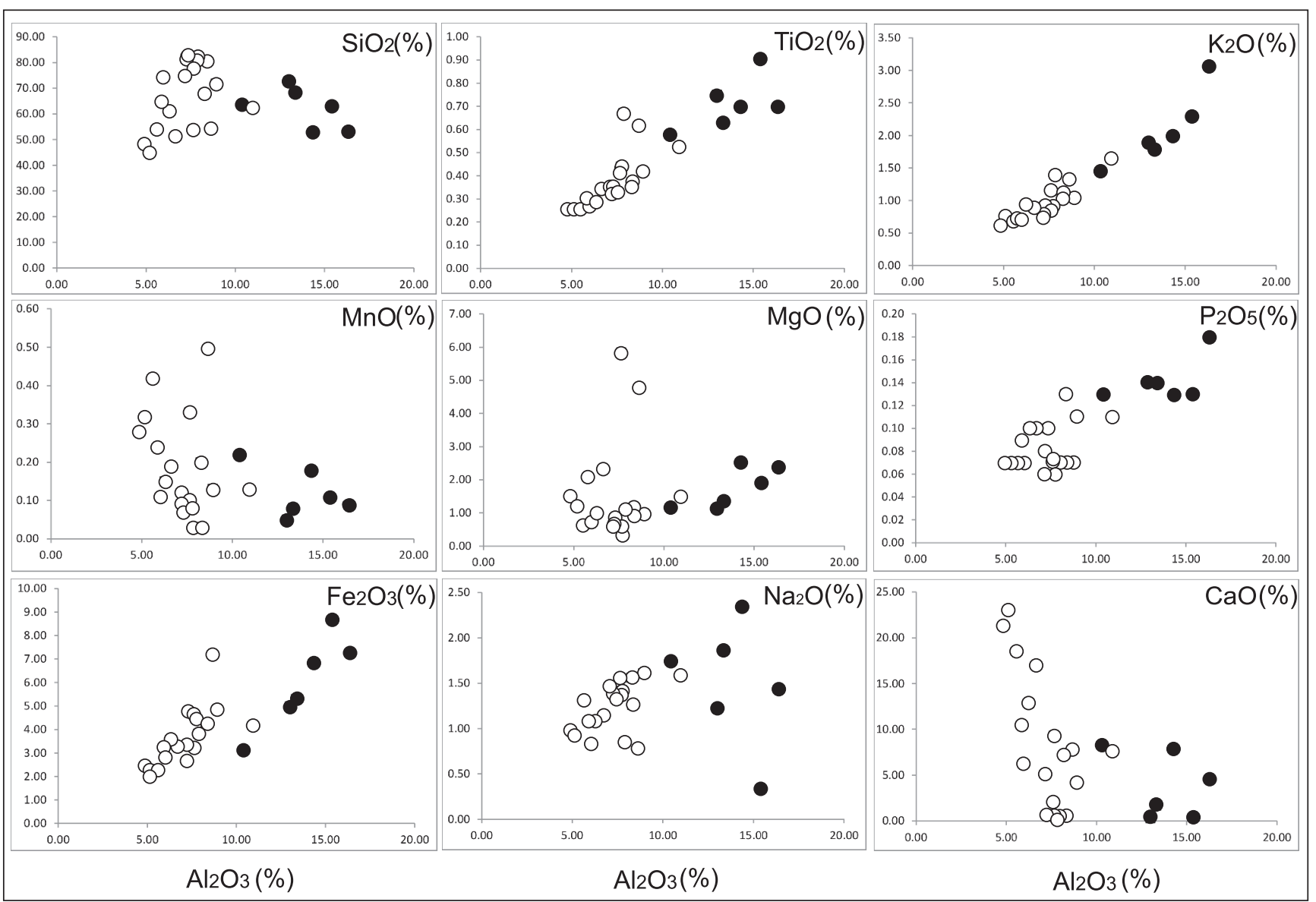

Fig. 8. Bivariate diagrams for sandstone and shale samples of the Shemshak Group

\section{INTERPRETATION AND DISCUSSION}

\section{PALAEOWEATHERING AND SEDIMENT RECYCLING}

Chemical weathering may modify the geochemistry and mineral composition of siliciclastic sediments during transport and deposition (Nesbitt and Young, 1982; McLennan et al., 1993; Ramos-Vázquez et al., 2017). The chemical index of alteration (CIA; Nesbitt and Young, 1982) is a common method to evaluate the relationship between alkali and alkaline earth elements, and the weathering history of siliciclastic rocks. Higher ClA values (80-100) reflect the removal of labile cations $\left(\mathrm{Na}^{+}\right.$, $\left.\mathrm{K}^{+}, \mathrm{Ca}^{2+}\right)$ relative to residual cations $\left(\mathrm{Al}^{+3}\right)$ and are an indicator of intense weathering in the source terrains, whereas lower values $(<60)$ represent lesser weathering (Fedo et al., 1995). The $\mathrm{CIA}$ can be calculated by an equation: $\mathrm{CIA}=\left[\mathrm{Al}_{2} \mathrm{O}_{3} /\left(\mathrm{Al}_{2} \mathrm{O}_{3}+\right.\right.$ $\left.\left.\mathrm{CaO}^{*}+\mathrm{Na}_{2} \mathrm{O}+\mathrm{K}_{2} \mathrm{O}\right)\right] \cdot 100$. All the oxides are in molecular proportion and $\mathrm{CaO}^{*}$ represents $\mathrm{Ca}$ in silicate minerals. The $\mathrm{CIA}$ values in the Shemshak Group range from $\sim 52$ to 71 and $\sim 58$ to 81 in the sandstones and shales, respectively. These values indicate a moderate degree of chemical weathering in the source areas. Suttner and Dutta (1986) proposed a bivariate diagram of $\mathrm{SiO}_{2}$ versus $\mathrm{Al}_{2} \mathrm{O}_{3}+\mathrm{K}_{2} \mathrm{O}+\mathrm{Na}_{2} \mathrm{O}$ to determine the climatic condition of the source area. This plot revealed a high probability of a humid climatic condition in the source area (Fig. 11).

Leaching of $\mathrm{Sr}$ compared to $\mathrm{Rb}$ is also an indicator of intense chemical weathering and diagenesis (Nesbitt and Young, 1982). High $\mathrm{Rb} / \mathrm{Sr}$ ratios (>1) are indicators of sediment recycling and strong weathering (McLennan et al., 1993). The Rb/Sr ratios in Shemshak Group sandstones $(\sim 0.1-0.87$; average = $0.37)$ and shales $(\sim 0.35-0.99$; average $=0.66)$ are lower than the average PAAS (0.80; Taylor and McLennan, 1985) suggesting a simple recycling history. Recycling of sediments with strong and repetitive weathering under oxidizing conditions may increase the fractionation of $\mathrm{Th}$ and $\mathrm{U}$, and the oxidation of $\mathrm{U}^{+4}$ to $U^{+6}$ leads to a loss of $U$, which consequently causes an increase in the $T h / U$ ratio. The $T h / U$ ratios of the Shemshak Group sandstones $(\sim 1.9-5.5 ;$ mean $=3.6)$ and shales $(\sim 3.4-4.3$; mean $=3.8)$ are similar to the average value of UCC (3.8; McLennan and Taylor, 1991), indicating a moderate degree of chemical weathering in the source area and a simple recycling history. Based on the geochemical indicators and plant remains such as Dictyophyllum, Otozomites, Pterophyllum and Zamites, Najafi-Hajipour (2009) proposed a subtropical climate for the Shemshak Group.

The Index of Compositional Variability (ICV; Cox et al., 1995 ) is commonly used by researchers to evaluate sediment maturity (Armstrong-Altrin, 2009; Tapia-Fernandez et al., 2017; Hernández-Hinojosa et al., 2018). The ICV can be calculated based on the equation ICV $=\left(\mathrm{CaO}+\mathrm{K}_{2} \mathrm{O}+\mathrm{Na}_{2} \mathrm{O}+\mathrm{Fe}_{2} \mathrm{O}_{3}{ }^{\mathrm{t}}+\right.$ $\left.\mathrm{MgO}+\mathrm{MnO}+\mathrm{TiO}_{2}\right) / \mathrm{Al}_{2} \mathrm{O}_{3}$. The ICV values of the Shemshak Group range from 0.99 to 5.58 (mean $=2.40$ ) and 0.79 to 1.56 (mean $=1.16)$ in the sandstones and shales, respectively higher than that of PAAS ( 0.89) indicating that these samples represent first cycle immature sediments and are related to areas with an active tectonic regime (Cox et al., 1995). The moderate weathering in the source area also reveals that the sediments were probably supplied from a rapidly uplifted region. 

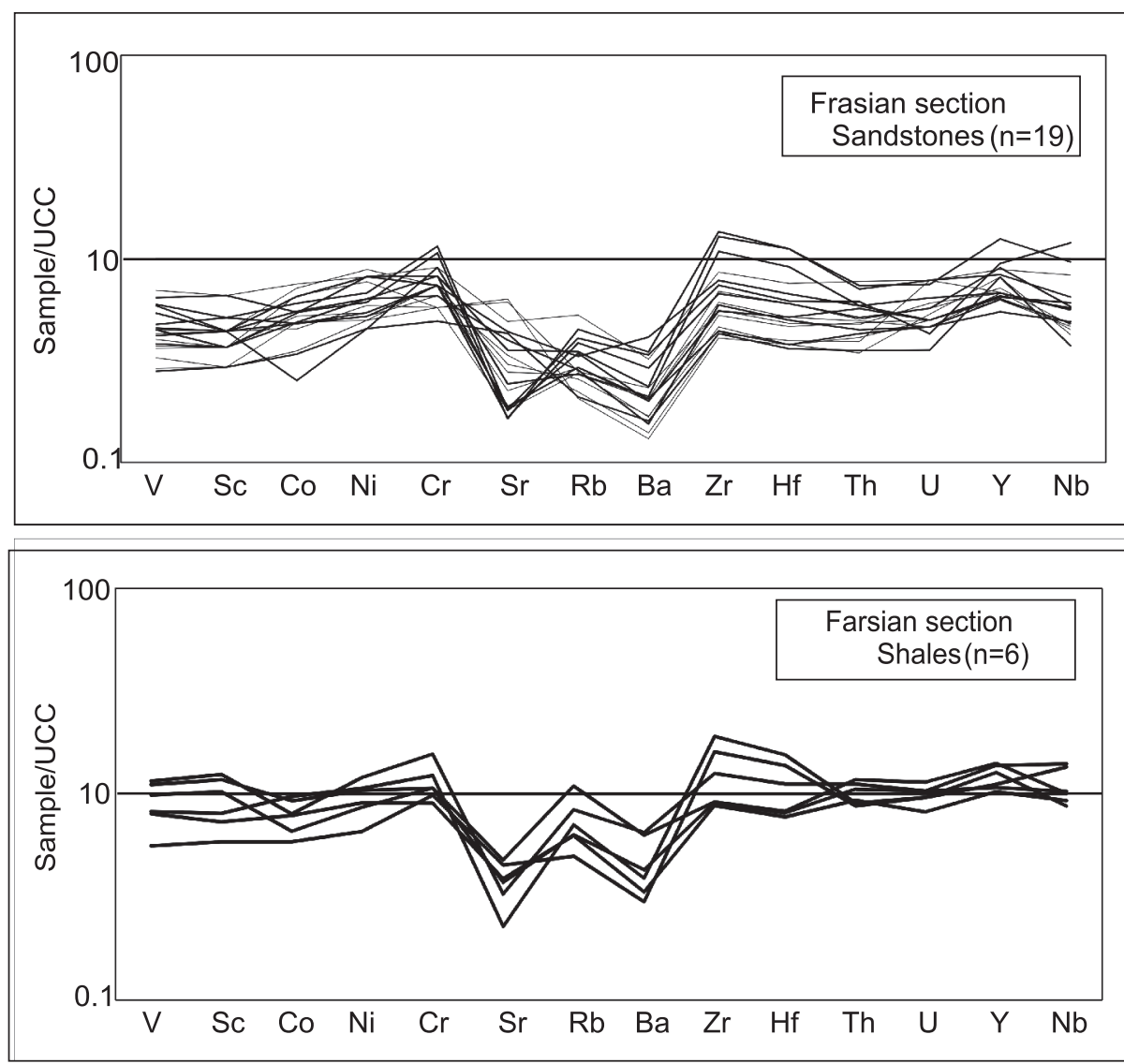

Fig. 9. Multi-element spider diagrams for sandstone and shale samples of the Shemshak Group, normalized against average upper continental crust (Taylor and McLennan, 1985)
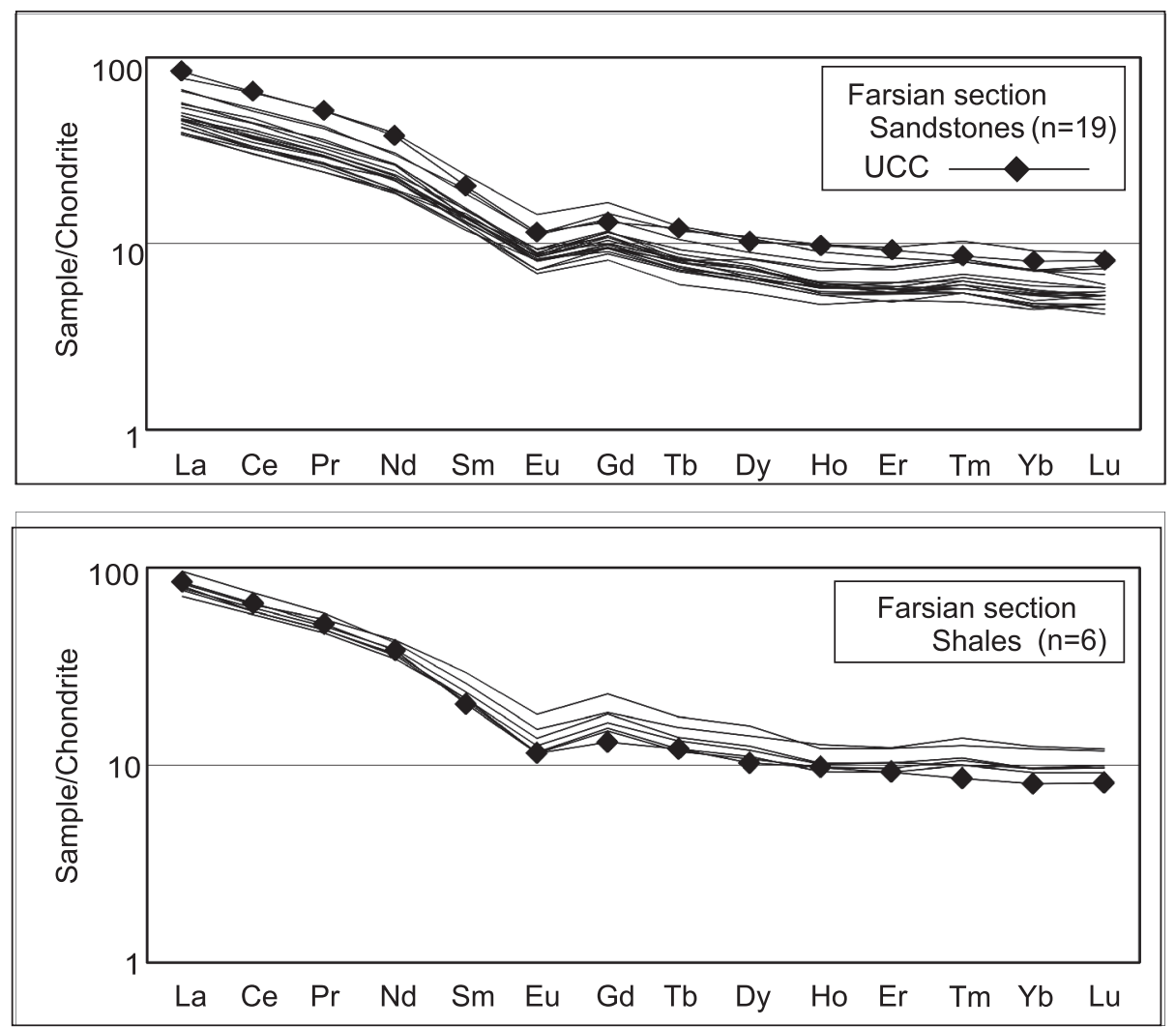

Fig. 10. Chondrite-normalised REE patterns for sandstone and shale samples of the Shemshak Group (Taylor and McLennan, 1985) 


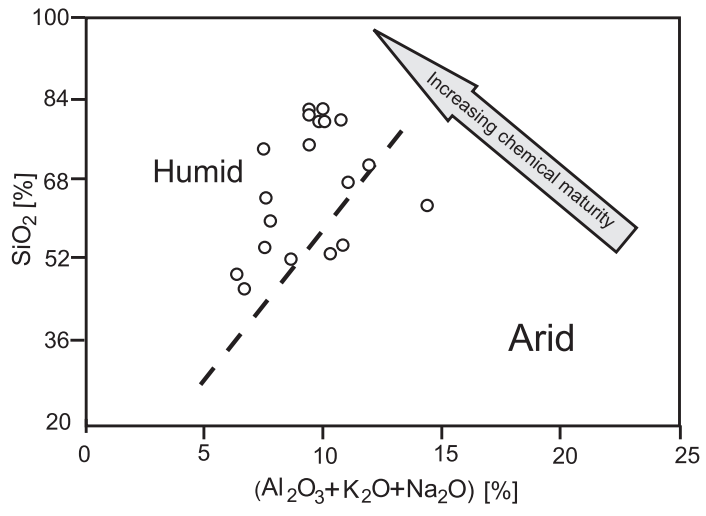

Fig. 11. $\mathrm{SiO}_{2}$ (wt. \%) versus $\left(\mathrm{Al}_{2} \mathrm{O}_{3}+\mathrm{K}_{2} \mathrm{O}+\mathrm{Na}_{2} \mathrm{O}\right)$ bivariate diagram for sandstones of the Shemshak Group (after Suttner and Dutta, 1986)

\section{PROVENANCE IMPLICATIONS}

The modal composition of the Shemshak Group sandstones indicates the quartzolithic petrofacies, which suggests that these sandstones are composed of recycled sedimentary materials. The geochemistry of clastic rocks is also widely used to infer the composition of the source rocks and the tectonic setting of the source area (Gabo et al., 2009; Verma and Armstrong-Altrin, 2013, 2016; Armstrong-Altrin et al., 2015; Basu, 2016; Verma et al., 2016). The major element based discriminant function diagram of Roser and Korsch (1988) was used to discriminate the provenance of sandstone and shales of the Shemshak Group, and this suggests that the sediments were derived from quartzose sedimentary (felsic) and intermediate igneous provenances (andesitic) (Fig. 12A). In addition, a bivariate diagram of $\mathrm{TiO}_{2}$ versus $\mathrm{Zr}$ shows that the source rocks of the Shemshak sediments were more felsic than intermediate types (Hayashi et al., 1997; Fig. 12B). Trace elements in siliciclastic deposits can be used to investigate the source rocks, because incompatible elements (e.g., Th, $\mathrm{U}, \mathrm{Zr}, \mathrm{Nb}, \mathrm{Y}$ ) are enriched in felsic rocks and compatible elements (e.g., Ni, Co, Cr, V) are abundant in mafic and ultramafic rocks (Cullers, 2000; Armstrong-Altrin et al., 2004). However, a recent study by Saha et al. (2010) shows that although the trace element concentrations in siliciclastic sediments are suitable to discriminate felsic and mafic rocks, a mafic source does not necessarily imply arc-derivation. Sedimentary processes such as weathering and diagenesis do not significantly affect REE, Th and Sc contents (Mongelli et al., 2006) though the relative mobility of LREE and HREE may vary with redox conditions (Basu et al., 2016). A few trace elements such as $\mathrm{Zr}, \mathrm{Hf}$, and $\mathrm{Ti}$ are strongly influenced by fractionation of heavy minerals and hydraulic sorting (McLennan and Taylor, 1991). A $\mathrm{Zr} / \mathrm{Sc}-\mathrm{Th} / \mathrm{Sc}$ diagram proposed by McLennan et al. (1993) is used to infer source rock composition, and this indicates felsic and intermediate source rocks for the Shemshak Group (Fig. 12C). A bivariate diagram of $\mathrm{La} / \mathrm{Th}-\mathrm{Hf}$ is also used to discriminate source area types (Fig. 12D; Floyd and Leveridge, 1987). On this diagram (Fig. 12D), most shale samples plot in the mixed felsic and mafic source fields. Chondrite-normalized REE patterns were also used to reveal the source area composition of the Shemshak samples (Fig. 10). Almost all samples have clear negative Eu anomalies, reflecting their derivation from a felsic provenance (e.g., Yang et al., 2012; Wang et al., 2018).
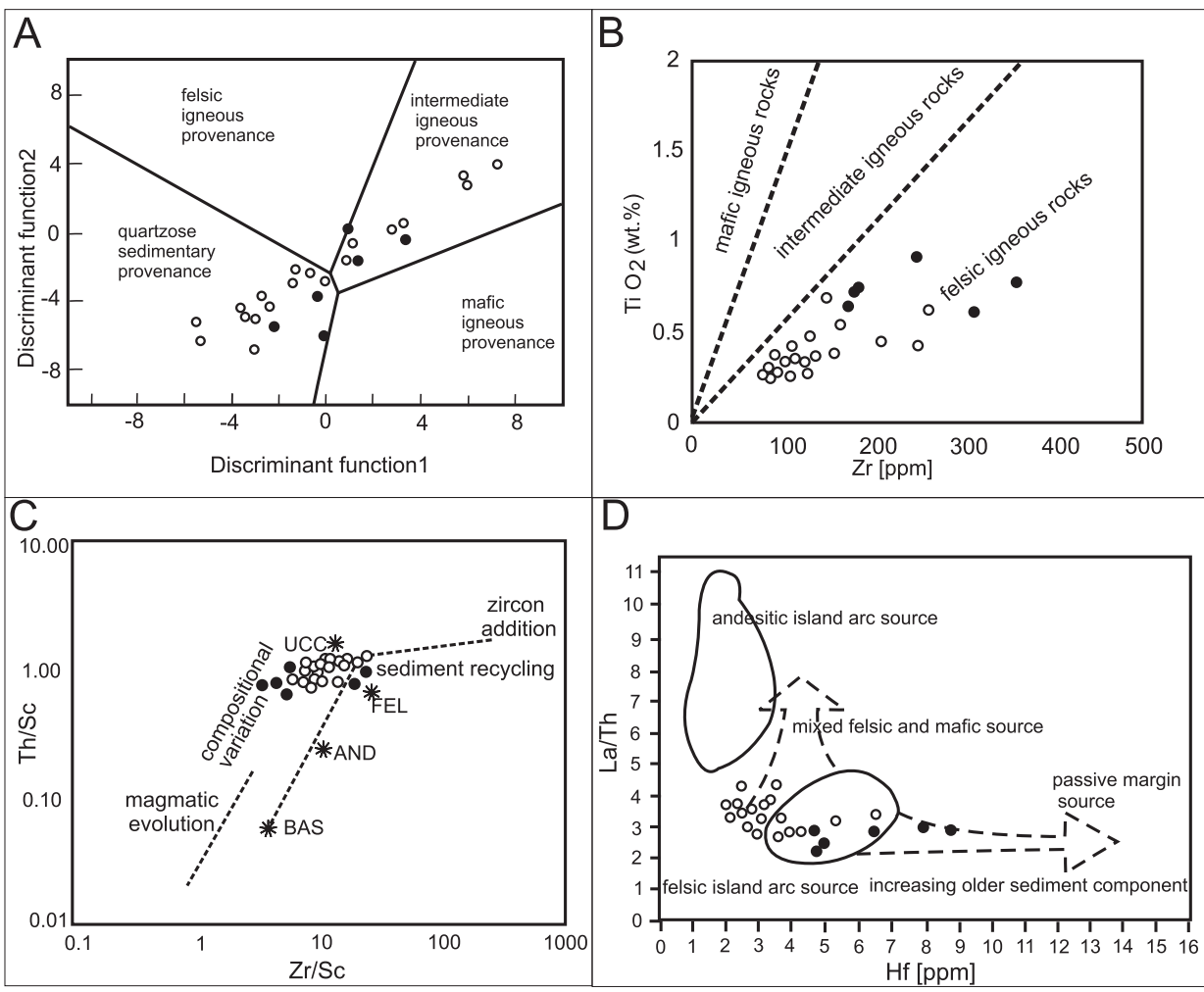

Fig. 12. Discrimination diagrams for sandstone and shale samples from the Shemshak Group

A - provenance discrimination diagram (Roser and Korsch, 1988); $\mathbf{B}-\mathrm{TiO}_{2}$ versus $\mathrm{Zr}$ bivariate diagram (Hayashi et al., 1997); C - Zr/Sc versus Th/Sc bivariate diagram (McLennan et al., 1993); D - La/Th versus Hf bivariate diagram (Floyd and Leveridge, 1987) 

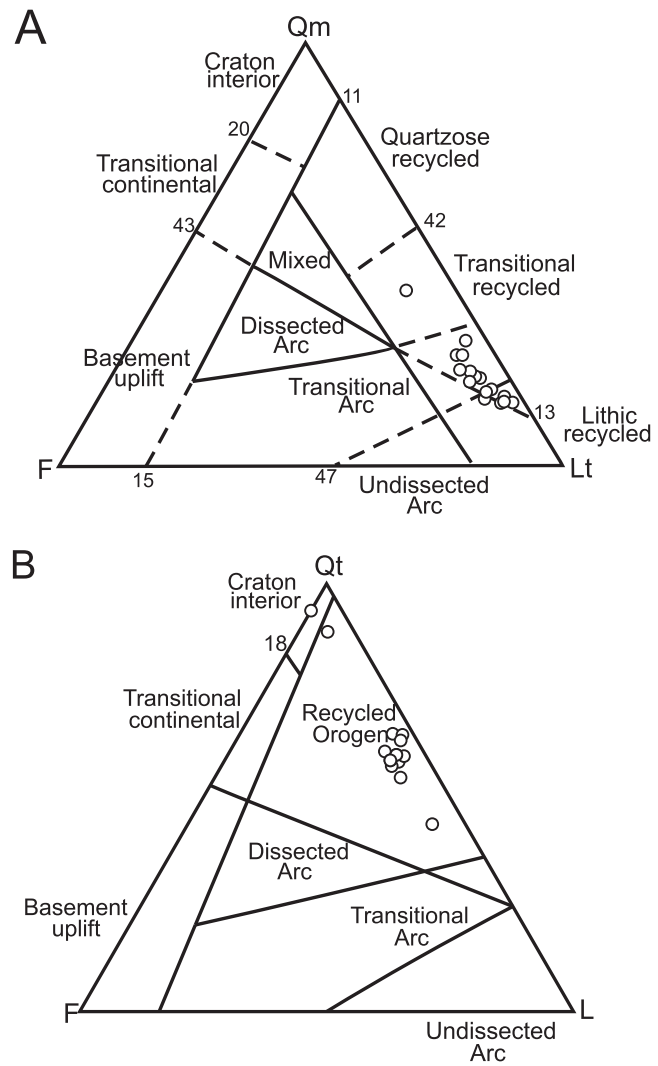

Fig. 13. Provenance discrimination diagrams (after Dickinson et al., 1983)

A - Qm-F-Lt; B - Qt-F-L

\section{TECTONIC SETTING}

One of the main factors which controls the type of detrital grains and geochemical composition of clastic sedimentary rocks is the tectonic setting of the source area (Dickinson and Suczek, 1979; Roser and Korsch, 1986; Armstrong-Altrin, 2015), because rocks from various tectonic settings have different mineralogical and chemical compositions (Bhatia and Crook, 1986; Verma and Armstrong-Altrin, 2013, 2016). Besides the close relationship between sand composition and tectonic setting, quantitative detrital modes of sandstones are also used to identify the tectonic setting of ancient basins of the source terranes (e.g., Dickinson and Suczek, 1979; Basu, 2016). Triangular plots of Qm-F-Lt and Qt-F-L (Dickinson et al., 1983) suggest that the Shemshak sandstones were derived from lithic to transitional recycled sources (Fig. 13). Sandstones

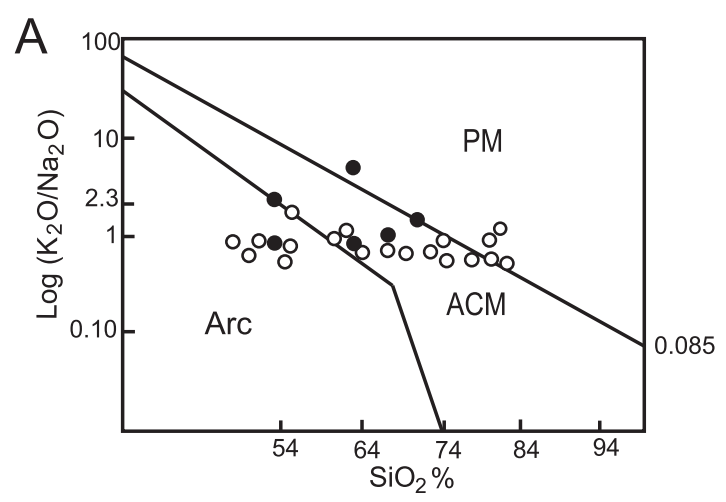

B

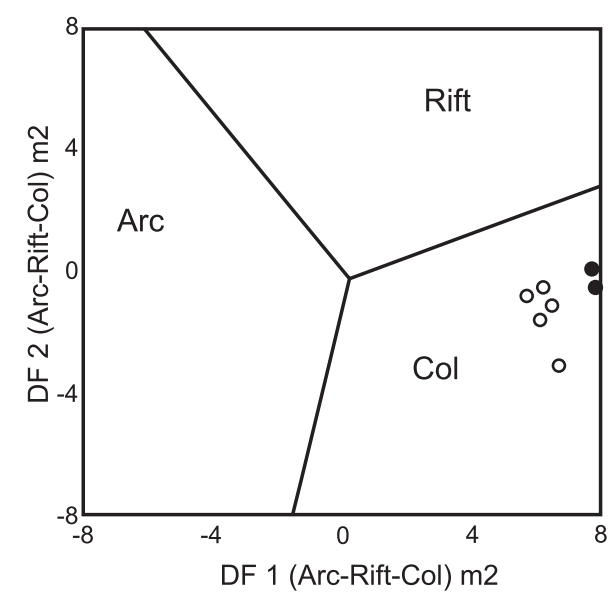

C

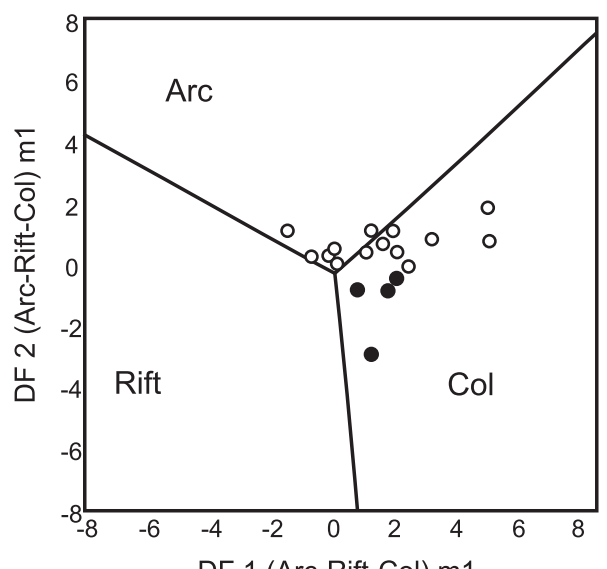

DF 1 (Arc-Rift-Col) m1

A - discrimination diagram based on major element composition (after Roser and Korsch, 1986; ARC - oceanic island arc; ACM - active continental margin; PM - passive margin). B - major element based tectonic discrimination plots for the low-silica samples (after Verma and Armstrong-Altrin, 2013): DF1(Arc-Rift-Col)m1 $=\left[-0.263 \times \ln \left(\mathrm{TiO}_{2} / \mathrm{SiO}_{2}\right)_{\mathrm{adj}}\right]$ $\left.+\left[0.604 \times \ln \left(\mathrm{Al}_{2} \mathrm{O}_{3} / \mathrm{SiO}_{2}\right)_{\text {adj }}\right]+\left[-1.725 \times \ln \left(\mathrm{Fe}_{2} \mathrm{O}_{3} \mathrm{t} / \mathrm{SiO}\right)_{2}\right)_{\mathrm{adj}}\right]+[0.660 \times$ $\left.\ln \left(\mathrm{MnO} / \mathrm{SiO}_{2}\right)_{\mathrm{adj}}\right]+\left[2.191 \times \ln \left(\mathrm{MgO} / \mathrm{SiO}_{2}\right)_{\mathrm{adj}}\right]+\left[0.144 \times \ln \left(\mathrm{CaO} / \mathrm{SiO}_{2}\right)_{\mathrm{adj}}\right]+$ $\left[-1.304 \times \ln \left(\mathrm{Na}_{2} \mathrm{O} / \mathrm{SiO}_{2}\right)_{\mathrm{adj}}\right]+\left[0.054 \times \ln \left(\mathrm{K}_{2} \mathrm{O} / \mathrm{SiO}_{2}\right)_{\mathrm{adj}}\right]+[-0.330 \times$ $\left.\ln \left(\mathrm{P}_{2} \mathrm{O} 5 / \mathrm{SiO}_{2}\right)_{\text {adj }}\right]+1.588$. DF2(Arc-Rit-Col)m1 $1=\left[-1.196 \times \operatorname{In}\left(\mathrm{TiO}_{2} / \mathrm{SiO}_{2}\right)_{\text {adj }}\right]+$ $\left[1.604 \times \ln \left(\mathrm{Al}_{2} \mathrm{O}_{3} / \mathrm{SiO}_{2}\right)_{\mathrm{adj}}\right]+\left[0.303 \times \ln \left(\mathrm{Fe}_{2} \mathrm{O}_{3} \mathrm{t} / \mathrm{SiO}_{2}\right)_{\mathrm{adj}}\right]+[0.436 \times$ $\left.\ln \left(\mathrm{MnO} / \mathrm{SiO}_{2}\right)_{\mathrm{adj}}\right]+\left[0.838 \times \ln \left(\mathrm{MgO} / \mathrm{SiO}_{2}\right)_{\mathrm{adj}}\right]+\left[-0.407 \times \ln \left(\mathrm{CaO} / \mathrm{SiO}_{2}\right)_{\mathrm{adj}}\right]+$ $\left\{1.021 \times \ln \left(\mathrm{Na}_{2} \mathrm{O} / \mathrm{SiO}_{2}\right)_{\text {adj }}\right]+\left[-1.706 \times \ln \left(\mathrm{K}_{2} \mathrm{O} / \mathrm{SiO}_{2}\right)_{\mathrm{adj}}\right]+[-0.126 \times$ $\ln \left(\mathrm{P}_{2} \mathrm{O}_{5} / \mathrm{SiO}_{2}\right)_{\text {adj] }}$ - 1.068. C - major element tectonic discrimination plot for the high-silica samples (Verma and Armstrong-Altrin, 2013): DF1 (Arc-Rift-Col)m2 $=\left[0.608 \times \ln \left(\mathrm{TiO}_{2} / \mathrm{SiO}_{2}\right)_{\mathrm{adj}}\right]+\left[-1.854 \times \ln \left(\mathrm{Al}_{2} \mathrm{O}_{3} / \mathrm{SiO}_{2}\right)_{\mathrm{adj}}\right]$ $+\left[0.299 \times \ln \left(\mathrm{Fe}_{2} \mathrm{O}_{3} \mathrm{t} / \mathrm{SiO}_{2}\right)_{\mathrm{adij}}\right]+\left[-0.550 \times \ln \left(\mathrm{MnO} / \mathrm{SiO}_{2}\right)_{\mathrm{adj}}\right]+[0.120 \times$ $\left.\ln \left(\mathrm{MgO} / \mathrm{SiO}_{2}\right)_{\mathrm{adj}}\right]+\left[0.194 \times \ln \left(\mathrm{CaO} / \mathrm{SiO}_{2}\right)_{\mathrm{adj}}\right]+\left[-1.510 \times \ln \left(\mathrm{Na}_{2} \mathrm{O} / \mathrm{SiO}_{2}\right)_{\mathrm{adj}}\right]+$ $\left[1.941 \times \ln \left(\mathrm{K}_{2} \mathrm{O} / \mathrm{SiO}_{2}\right)_{\mathrm{adj}}\right]+\left[0.003 \times \ln \left(\mathrm{P}_{2} \mathrm{O}_{5} / \mathrm{SiO}_{2}\right)_{\mathrm{adj}}\right]-0.294$. DF2(Arc-Rit-Col)m2 $=\left[-0.554 \times \ln \left(\mathrm{TiO}_{2} / \mathrm{SiO}_{2}\right)_{\text {adj }}\right]+\left[-0.995 \times \ln \left(\mathrm{Al}_{2} \mathrm{O}_{3} / \mathrm{SiO}_{2}\right)_{\text {adi }}\right]+$ $\left[1.765 \times \ln \left(\mathrm{Fe}_{2} \mathrm{O}_{3} \mathrm{t} / \mathrm{SiO}_{2}\right)_{\mathrm{adj}}\right]+\left[-1.391 \times \ln \left(\mathrm{MnO} / \mathrm{SiO}_{2}\right)_{\mathrm{ad}}\right]+[-1.034 \times$ $\left.\ln \left(\mathrm{MgO} / \mathrm{SiO}_{2}\right)_{\mathrm{adj}}\right]+\left[0.225 \times \ln \left(\mathrm{CaO} / \mathrm{SiO}_{2}\right)_{\mathrm{adj}}\right]+\left[0.713 \times \ln \left(\mathrm{Na}_{2} \mathrm{O} / \mathrm{SiO}_{2}\right)_{\mathrm{adj}}\right]+$ $\left[0.330 \times \ln \left(\mathrm{K}_{2} \mathrm{O} / \mathrm{SiO}_{2}\right)_{\mathrm{adj}}\right]+\left[0.637 \times \ln \left(\mathrm{P}_{2} \mathrm{O}_{5} / \mathrm{SiO}_{2}\right)_{\text {adj }}\right]-3.631$ 
composed of recycled sedimentary materials have quartz and abundant lithic fragments of sedimentary-metasedimentary composition (Dickinson and Suczek, 1979). This quartzolithic petrofacies identified in sandstones of the Shemshak Group is also reported in the north of Alborz Range (Zanchi et al., 2009) and Central Iran (Salehi et al., 2017).

The discrimination diagrams of Bhatia (1983) and Roser and Korsch (1986) have been used commonly to decipher the tectonic setting of ancient sedimentary basins (Nowrouzi et al., 2014; Jafarzadeh et al., 2014; Ogala et al., 2015; Vosoughi Moradi et al., 2016). In this study, we used three diagrams based on major, trace and rare earth elements for deciphering the tectonic setting of the source area. As shown on the widely used $\mathrm{K}_{2} \mathrm{O} / \mathrm{Na}_{2} \mathrm{O}$ logarithmic ratio against $\mathrm{SiO}_{2}$ diagram of Roser and Korsch (1986), most of the samples plot in the active continental margin (ACM) field and six samples including a shale sample plot in the continental island arc field $(\mathrm{ClA})$. Also three samples plot in the passive continental margin field but near to the boundary with the active margin field (Fig. 14A). Armstrong-Altrin and Verma (2005) evaluated the tectonic discrimination diagrams of Roser and Korsch (1986) using Miocene to Recent deposits and identified a low percentage success rate, which varies from 31.5 to $52.3 \%$. Recently, based on the log-ratio transformation ratio of major oxides, Verma and Armstrong-Altrin (2013) proposed multi-dimensional tectonic discrimina- tion diagrams for high silica $\left(\mathrm{SiO}_{2}=63-95 \%\right)$ and low silica $\left(\mathrm{SiO}_{2}=35-63 \%\right)$ samples (Fig. 14B, C). On these discrimination diagrams (Fig. 14B, C), although few sandstone samples plot in the arc field most of them plot in the collision field. These results suggest a collisional setting for the Shemshak Group. As mentioned previously, we compared the geochemical results with petrographic data. We did not find any evidence for an island arc setting using petrographic data and so consider that a collision setting may be more reasonable for the Shemshak Group. Considering the palaeogeography, the Shemshak Group is commonly regarded as the Cimmerian foreland molasse produced by the Early Cimmerian orogeny (collision between the Iran and Turan plates) during the early Late Triassic (Rad, 1986; Alavi, 1996; Wilmsen et al., 2009). Fürsich et al. (2006) showed that the evolution of the depositional basin of the Shemshak Group is complex. Wilmsen et al. (2009) stated that initial Cimmerian collision started with synorogenic peripheral foreland deposition in the Late Triassic while simultaneously the Lower Shemshak sediments were deposited (Fig. 15A). Change from the Elikah Formation (platform carbonates) to the Shemshak Group (continental/marine siliciclastic deposits) occurred between the Carnian and the Norian (Zanchi et al., 2009). Neotethys subduction below Iran shifted south in the Norian and rapid uplift of the Cimmerides occurred after slab break-off around the Triassic-Jurassic boundary. This was fol-

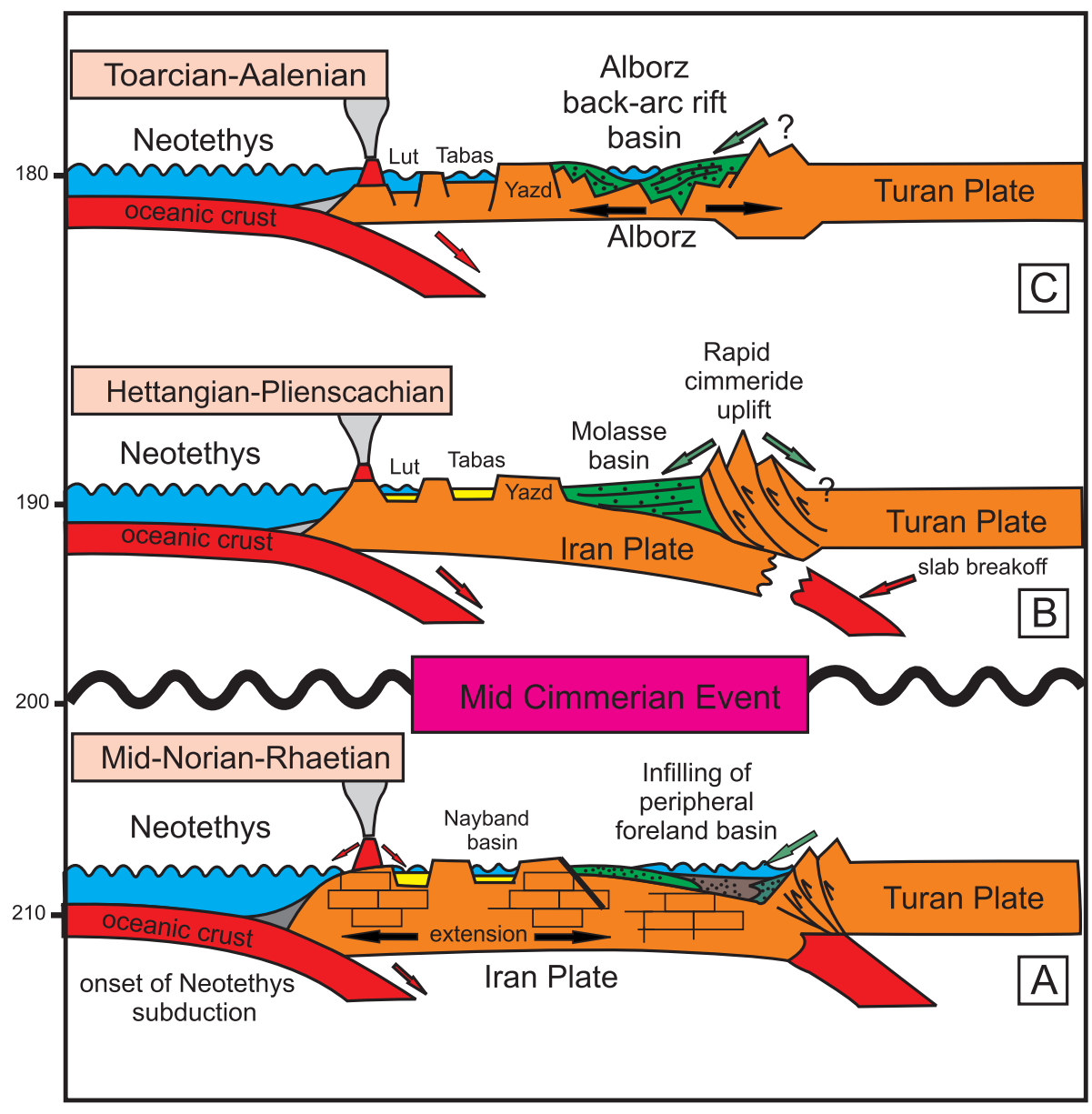

Fig. 15. Structural evolution of the Alborz Basin during the deposition of Shemshak Group sediments in an active continental margin (A and B) and back arc setting (C) (modified from Wilmsen et al., 2009) 
lowed by the deposition of Liassic post-orogenic molasse (middle Shemshak) sediments (Wilmsen et al., 2009; Fig. 15B). During the Toarcian-Aalenian, the time of upper Shemshak Group deposition, Neotethys backarc rifting created a deep marine basin and led to the deposition of organic-rich fine-grained siliciclastic sediments during the Aalenian, which filled the young rifted basin (Fig. 15C). Coincidence of the extensional event with the Eo-Cimmerian orogeny suggests that it may have been an effect of the peripheral bulging of the foreland induced by the collision (Zanchi et al., 2009).

\section{CONCLUSIONS}

Modal and mineral compositions of Shemshak Group sandstones indicate that they are composed dominantly of quartz (monocrystalline and polycrystalline), feldspars and rock fragments (sedimentary and metamorphic rock fragments) and provide evidence of distinctive quartzolithic petrofacies. The quartzolithic composition of the sandstones reveals a "recycled orogenic provenance". CIA values indicate that the source area underwent a moderate grade of chemical weathering and the
$\mathrm{SiO}_{2}$ versus $\mathrm{Al}_{2} \mathrm{O}_{3}+\mathrm{K}_{2} \mathrm{O}+\mathrm{Na}_{2} \mathrm{O}$ diagram indicates a humid climate in the source area. Various provenance discrimination diagrams based on major elements show mixed recycled sedimentary (felsic) and intermediate (andesitic) igneous rocks, which dominate in the source area. Trace and REE compositions also suggest mixed felsic and intermediate provenances for the Shemshak Group detrital deposits. On the tectonic discrimination diagrams, a few samples plot in the arc field and most of the sandstone and shale samples plot in the collision field, while the petrographic study did not indicate an island arc setting for the Shemshak sandstones. These results suggest a collisional setting for the Shemshak Group, which is consistent with the palaeogeographic evolution of Alborz and Central Iran during the Middle Triassic to Jurassic interval (Wilmsen et al., 2009).

Acknowledgements. We would like to thank the Editor and the reviewers A. Basu, S.K. Verma, and an anonymous reviewer for their constructive comments, which significantly improved our presentation. JSA is grateful to the Institute of Marine Sciences and Limnology (ICML), UNAM, Internal project (no. 616)

\section{REFERENCES}

Abbassi, N., Madanipour, S., 2014. Dinosaur tracks from the Jurassic Shemshak Group in the Central Alborz Mountains (Northern Iran). Geolgica Carpathica, 65: 99-115.

Alavi, M., 1996. Tectonostratigraphic synthesis and structural style of the Alborz Mountains system in northern Iran. Journal of Geodynamics, 21: 1-33.

Armstrong-Altrin, J.S., 2009. Provenance of sands from Cazones, Acapulco, and Bahía Kino beaches, Mexico. Revista Mexicana de Ciencias Geológicas, 26: 764-782.

Armstrong-Altrin, J.S., 2015. Evaluation of two multidimensional discrimination diagrams from beach and deep-sea sediments from the Gulf of Mexico and their application to Precambrian clastic sedimentary rocks. International Geology Review, 57: 1446-1446.

Armstrong-Altrin, J.S., Verma, S.P., 2005. Critical evaluation of six tectonic setting discrimination diagrams using geochemical data of Neogene sediments from known tectonic settings. Sedimentary Geology, 177: 115-129.

Armstrong-Altrin, J.S., Lee, Y.I., Verma, S.P., Ramasamy, S., 2004. Geochemistry of sandstones from the Upper Miocene Kudankulam Formation, southern India: implications for provenance, weathering, and tectonic setting. Journal of Sedimentary Research, 74: 285-297.

Armstrong-Altrin, J.S., Nagarajan, R., Madhavaraju, J., Rosales-Hoz, L., Lee, Y.I., Balaram, V., Cruz-Martinez, A., Avila-Ramirez, G., 2013. Geochemistry of the Jurassic and upper Cretaceous shales from the Molango Region, Hidalgo, eastern Mexico: implications for source-area weathering, provenance, and tectonic setting. Comptes Rendus Geoscience, 345: 185-202.

Armstrong-Altrin, J.S., Nagarajan, R., Lee, Y.I., Kasper-Zubillaga, J.J., Córdoba-Saldańa, L.P., 2014. Geochemistry of sands along the San Nicolás and San Carlos beaches, Gulf of California, Mexico: implication for provenance. Turkish Journal of Earth Sciences, 23: 533-558.

Armstrong-Altrin, J.S., Nagarajan, R., Balaram, V., Natalhy-Pineda, O., 2015. Petrography and geochemistry of sands from the Chachalacas and Veracruz beach areas, western Gulf of Mexico, Mexico: constraints on provenance and tectonic setting. Journal of South American Earth Sciences, 64: 199-216.

Armstrong-Altrin, J.S., Lee, Y.I., Kasper-Zubillaga, J.J., Trejo-Ramírez, E., 2017. Mineralogy and geochemistry of sands along the Manzanillo and El Carrizal beach areas, southern Mexico: implications for palaeoweathering, provenance, and tectonic setting. Geological Journal, 52: 559-582.

Armstrong-Altrin, J.S., Ramos-Vázquez, M.A., Zavala-León, A.C., Montiel-García, P.C., 2018. Provenance discrimination between Atasta and Alvarado beach sands, western Gulf of Mexico, Mexico: constraints from detrital zircon chemistry and $\mathrm{U}-\mathrm{Pb}$ geochronology. Geological Journal, doi: 10.1002/gj.3122

Assereto, R., 1966. The Jurassic Shemshak Formation in central Alborz (Iran). Rivista Italiana di Paleontologia e Stratigrafia, 72: 1133-1182.

Basu, A., 2016. Evolution of siliciclastic provenance inquiries: a critical appraisal. In: Sediment Provenance (ed. R. Mazumder): 5-23. Elsevier Amsterdam, Netherlands.

Basu, A., Bickford, M.E., Deasy, R., 2016. Inferring tectonic provenance of siliciclastic rocks from their chemical compositions: a dissent. Sedimentary Geology, 336: 26-35.

Bhatia, M.R., 1983. Plate tectonics and geochemical composition of sandstones. Journal of Geology, 91: 611-627.

Bhatia, M.R., Crook, K.A.W., 1986. Trace element characteristics of greywackes and tectonic setting discrimination of sedimentary basins. Contributions to Mineralogy and Petrology, 92: 181-193.

Corsin, P., Stampfli, G., 1977. La formation de Shemshak dans l'Elburz oriental (Iran). Flore-Stratigraphie-Paléogéographie. Geobios, 10: 509-571.

Cox, R., Lowe, D.R., Cullers, R.L., 1995. The influence of sediment recycling and basement composition on evolution of mudrock chemistry in the south-western United States. Geochimica et Cosmochimica Acta, 59: 2919-2940.

Cullers, R.L., 2000. The geochemistry of shales, siltstones and sandstones of Pennsylvanian-Permian age, Colorado, USA: implications for provenance and metamorphic studies. Lithos, 51: 181-203. 
Dickinson, W.R., Suczek, C.A., 1979. Plate tectonics and sandstone compositions. AAPG Bulletin, 63: 2164-2182.

Dickinson, W.R., Beard, L.S., Brakenridge, G.R., Erjavec, J.L., Ferguson, R.C., Inman, K.F., Knepp, R.A., Lindberg, F.A. Ryberg, P.T., 1983. Provenance of North American Phanerozoic sandstones in relation to tectonic setting. GSA Bulletin, 94: 222-235.

Fedo, C.M., Nesbitt, H.W., Young, G.M., 1995. Unraveling the effects of potassium metasomatism in sedimentary rocks and paleosols, with implications for paleoweathering conditions and provenance. Geology, 23: 921-924.

Floyd, P.A., Leveridge, B.E., 1987. Tectonic environment of the Devonian Gramscatho basin, south Cornwall: framework mode and geochemical evidence from turbiditic sandstones. Journal of the Geological Society, 144: 531-542.

Fürsich, F.T., Wilmsen, M., Seyed-Emami, K., Cecca, F., Majidifard, M.R., 2005. The upper Shemshak Formation (Toarcian-Aalenian) of the Eastern Alborz (Iran): biota and palaeoenvironments during a transgressive-regressive cycle. Facies, 51: $365-384$.

Fürsich, F.T., Wilmsen, M., Seyed-Emami, K., 2006. Ichnology of Lower Jurassic beach deposits in the Shemshak Formation at Shahmirzad, southeastern Alborz Mountains, Iran. Facies, 52: 599-610.

Fürsich, F.T., Wilmsen, M., Seyed-Emami, K., Majidifard, M.R., 2009. Lithostratigraphy of the Upper Triassic-Middle Jurassic Shemshak Group of Northern Iran. Geological Society Special Publications, 312: 129-160.

Fürsich, F.T., Brunet, M.-F., Auxičtre, J.-L., Munsch, H., 2017 Lower-Middle Jurassic facies patterns in the NW Afghan-Tajik Basin of southern Uzbekistan and their geodynamic context. Geological Society Special Publications, 427: 357-409.

Gabo, J.A.S., Dimalanta, C.B., Asio, M.G.S., Queańo, K.L., Yumul, G.P., Imai, A., 2009. Geology and geochemistry of the clastic sequence from northwestern Panay (Philippines): implications for provenance and geotectonic setting. Tectonophysics, 479: 111-119.

Hayashi, K., Fujisawa, H., Holland, H.D., Ohmoto, H., 1997. Geochemistry of $\sim 1.9 \mathrm{Ga}$ sedimentary rocks from northeastern Labrador, Canada. Geochimica et Cosmochimica Acta, 61: 4115-4137

Hernández-Hinojosa, V., Montiel-García, P.C., Armstrong-Altrin, J.S., Nagarajan, R., Kasper-Zubillaga, J.J., 2018. Textural and geochemical characteristics of beach sands along the western Gulf of Mexico, Mexico. Carpathian Journal of Earth and Environmental Sciences, 13: 161-174

Herron, M.M., 1988. Geochemical classification of terrigenous sands and shales from core or log data. Journal of Sedimentary Petrology, 58: 820-829.

Ingersoll, R.V., Bulard, T.F., Ford, R.L., Grimn, J.P., Pickle, J.P., Sares, S.W., 1984. The effect of grain size on detrital modes: a text of the Gazzi-Dickinson Point Counting method. Journal of Sedimentary Petrology, 54: 103-116.

Jafarzadeh, M., Harami, R.M., Amini, A., Mahboubi, A., Farzaneh, F., 2014. Geochemical constraints on the provenance of Oligocene-Miocene siliciclastic deposits (Zivah Formation) of NW Iran: implications for the tectonic evolution of the Caucasus. Arabian Journal of Geosciences, 7: 4245-4263.

McLennan, S.M., Taylor, S.R., 1991. Sedimentary rocks and crustal evolution: tectonic setting and secular trends. Journal of Geology, 99: 1-21.

McLennan, S.M., Hemming, S., McDaniel, D.K., Hanson, G.N., 1993. Geochemical approaches to sedimentation, provenance and tectonics. GSA Special Paper, 284: 21-40.

Mongelli, G., Critelli, S., Perri, F., Sonnino, M., Perrone, V., 2006. Sedimentary recycling, provenance and paleoweathering from chemistry and mineralogy of Mesozoic continental redbed mudrocks, Peloritani Mountains, Southern Italy. Geochemical Journal, 40: 197-209.

Moosavirad, S.M., Janardhana, M.R., Sethumadhav, M.S., Moghaddam, M.R., Shankara, M., 2011. Geochemistry of lower Jurassic shales of the Shemshak Formation, Kerman
Province, Central Iran: provenance, source weathering and tectonic setting. Chemie der Erde, 71: 279-288.

Moosavirad, S.M., Janardhana, M.R., Sethumadhav, M.S., Prakash Narasimha, K.N., 2012. Geochemistry of Lower Jurassic sandstones of Shemshak Formation, Kerman basin, Central Iran: Provenance, source weathering and tectonic setting. Journal of Geological Society of India, 79: 483-496.

Nagarajan, R., Armstrong-Altrin, J.S., Kessler, F.L., Hidalgo-Moral, E.L., Dodge-Wan, D., Taib, N.I., 2015. Provenance and tectonic setting of Miocene siliciclastic sediments, Sibuti formation, northwestern Borneo. Arabian Journal of Geosciences, 8: 8549-8565

Nagarajan, R., Armstrong-Altrin, J.S., Kessler, F.L., Jong, J., 2017. Petrological and geochemical constraints on provenance, paleoweathering and tectonic setting of clastic sediments from the Neogene Lambir and Sibuti Formations, Northwestern Borneo. In: Sediment Provenance (ed. R. Mazumder): 123-153. Elsevier Amsterdam, Netherlands.

Najafi-Hajipour, D., 2009. Encountered plant macrofossils of Shemshak Formation in Ghoznavi - Fasian area, along Shahrud-Azadshahr road (Eastern Alborz), Northern Iran: Regional stratigraphic implications and palaeoclimatic condition (in Persian). Sedimentary Facies, 2: 106-114.

Nesbitt, H.W., Young, G.M., 1982. Early Proterozoic climates and plate motions inferred from major element chemistry of lutites. Nature, 299: 715-717.

Nowrouzi, Z., Moussavi-Harami, R., Mahboubi, A., Gharaie, M.H.M., Ghaemi, F., 2014. Petrography and geochemistry of Silurian Niur sandstones, Derenjal Mountains, East Central Iran: implications for tectonic setting, provenance and weathering Arabian Journal of Geosciences, 7: 2793-2813.

Ogala, J.E., Olobaniyi, S.B., Omo-Irabor, O.O., Adaikpoh, E.O., 2015. Petrographic and geochemical study of the Maastrichtian Ajali Sandstone, North Central Nigeria. Geological Quarterly, 59 (1): 79-90.

Rad, F.K., 1986. A Jurassic delta in the eastern Alborz, NE Iran. Journal of Petroleum Geology, 9: 281-294.

Ramos-Vázquez, M.A., Armstrong-Altrin, J.S., Rosales-Hoz, L., Machain-Castillo, M.L., Carranza-Edwards, A., 2017. Geochemistry of deep-sea sediments in two cores retrieved at the mouth of the Coatzacoalcos river delta, western Gulf of Mexico, Mexico. Arabian Journal of Geosciences, 10: 148.

Roser, B.P., Korsch, R.J., 1986. Determination of tectonic setting of sandstone-mudstone suites using $\mathrm{SiO}_{2}$ content and $\mathrm{K}{ }_{2} \mathrm{O} / \mathrm{Na}_{2} \mathrm{O}$ ratio. Journal of Geology, 94: 635-650.

Roser, B.P., Korsch, R.J., 1988. Provenance signatures of sandstone-mudstone suites determined using discriminant function analysis of major-element data. Chemical Geology, 67: 119-139.

Saha, S., Banerjee, S., Burley, S., Saraswati, P., 2010. The influence of flood basaltic source terrains on the efficiency of tectonic setting discrimination diagrams: an example from the Gulf of Khambhat, western India. Sedimentary Geology, 228: 1-13.

Saidi, A., Brunet, M.F., Ricou, L.E., 1997. Continental accretion of the Iran Block to Eurasia as seen from Late Paleozoic to Early Cretaceous subsidence curves. Geodinamica Acta, 10: 189-208.

Salehi, M.A., Moussavi-Harami, R., Mahboubi, A., Fürsich, F.T., Wilmsen, M., Heubeck, C., 2017. A tectono-stratigraphic record of an extensional basin: the Lower Jurassic Ab-Haji Formation of east-central Iran. Swiss Journal of Geosciences, doi: 10.1007/s00015-017-0283-2

Seyed-Emami, K., 2003. Triassic in Iran. Facies, 48: 95-106.

Seyed-Emami, K., Fürsich, F.T., Wilmsen, M., Cecca, F., Majidifard, M.R., Schairer, G., Shekarifard, A., 2006. Stratigraphy and ammonite fauna of the upper Shemshak Formation (Toarcian Aalenian) at Tazareh, eastern Alborz, Iran. Journal of Asian Earth Sciences, 28: 259-275.

Shekarifard, A., Baudin, F., Schnyder, J., Seyed-Emami, K., 2009. Characterization of organic matter in the fine-grained siliciclastic sediments of the Shemshak Group (Upper Trias- 
sic-Middle Jurassic) in the Alborz Range, Northern Iran. Geological Society Special Publications, 312: 161-174.

Stampfli, G.M., Borel, G.D., 2002. A plate tectonic model for the Paleozoic and Mesozoic constrained by dynamic plate boundaries and restored synthetic oceanic isochrons. Earth and Planetary Science Letters, 196: 17-33.

Stocklin, J., 1968. Structural history and tectonics of Iran: a review. AAPG Bulletin, 52: 1229-1258.

Suttner, L.J., 1974. Sedimentary petrographic provinces: an evaluation. SEPM Special Publications, 21: 75-84.

Suttner, L.J., Dutta, P.K., 1986. Alluvial sandstone composition and paleoclimate; I. Framework mineralogy. Journal of Sedimentary Petrology, 56: 329-345.

Tapia-Fernandez, H.J., Armstrong-Altrin, J.S., Selvaraj, K., 2017. Geochemistry and U-Pb geochronology of detrital zircons in the Brujas beach sands, Campeche, Southwestern Gulf of Mexico, Mexico. Journal of South American Earth Sciences, 76: 346-361.

Taylor, S.R., McLennan, S.M., 1985. The Continental Crust: its Composition and Evolution. Blackwell, Oxford.

Verma, S.P., Armstrong-Altrin, J.S., 2013. New multi-dimensional diagrams for tectonic discrimination of siliciclastic sediments and their application to Pre-Cambrian basins. Chemical Geology, 355: 117-180.

Verma, S.P., Armstrong-Altrin, J.S., 2016. Geochemical discrimination of siliciclastic sediments from active and passive margin settings. Sedimentary Geology, 332: 1-12.

Verma, S.P., Díaz-González, L., Armstrong-Altrin, J.S., 2016. Application of a new computer program for tectonic discrimination of Cambrian to Holocene clastic sediments. Earth Science Informatics, 9: 151-165.

Vital, H., Stattegger, K., 2000. Major and trace elements of stream sediments from the lowermost Amazon River. Chemical Geology, 168: 151-168.

Vosoughi Moradi, A., Sari, A., Akkaya, P., 2016. Geochemistry of the Miocene Oil Shale (Hançilli Formation) in the Çankiri-Çorum Basin, Central Turkey: implications for paleoclimate conditions, source-area weathering, provenance and tectonic setting. Sedimentary Geology, 78: 136-150.

Wang, Z., Wang, J., Fu, X., Zhan, W., Armstrong-Altrin, J.S., Yu, F., Feng, X., Song, C., Zeng, S., 2018. Geochemistry of the Upper Triassic black mudstones in the Qiangtang Basin, Tibet: implications for paleoenvironment, provenance, and tectonic setting. Journal of Asian Earth Sciences, 76: 346-361.

Wilmsen, M., Fürsich, F.T., Seyed-Emami, K., Majidifard, M.R., 2009. An overview of the stratigraphy and facies development of the Jurassic system on the Tabas Block, east-central Iran. Geological Society Special Publications, 312: 323-343.

Yang, X.F., He, D.F., Wang, Q.C., Tang, Y., Tao, H.F., Li, D., 2012. Provenance and tectonic setting of the Carboniferous sedimentary rocks of the East Junggar Basin, China: evidence from geochemistry and $\mathrm{U}-\mathrm{Pb}$ zircon geochronology. Gondwana Research, 22: 567-584.

Zanchi, A., Zanchetta, S., Berra, F., Mattei, M., Garzanti, E., Molyneux, S., Nawab, A., Sabouri, J., 2009. The Eo-Cimmerian (Late? Triassic) orogeny in North Iran. Geological Society Special Publications, 312: 31-55. 